\title{
Heavy Metals Immobilization in Sewage Sludge Using Some Amendments
}

\section{Hala H. Gomah}

Department of Soils and Water, Fac. Agric., Assiut Univ., Assiut Egypt.

\begin{abstract}
THE ENHANCEMENT of sewage sludge to decrease its toxic effects on living organisms due to the high content of heavy metals $(\mathrm{Cd}, \mathrm{Cr}, \mathrm{Ni}$ and $\mathrm{Pb})$ was studied using some organic and inorganic materials. Four materials (Silica gel, Cement Bypass, Rock phosphate and Charcoal activated carbon) were mixed with the sewage sludge in three rates $(5,15$ and $25 \%)$ and the mixture of each two materials at a rate of $15 \%$ of each. Results indicated that DTPA extractable Cd, Ni and $\mathrm{Pb}$ decreased from $0.895,12.097$ and $26.02 \mathrm{ppm}$ in the control to $0.376,3.13$ and $9.06 \mathrm{ppm}$, respectively $(58,74$ and $65 \%$ reduction, respectively, compared with the control) with $25 \%$ of rock phosphate application. The lowest extracted $\mathrm{Cr}$ was obtained by the application of $25 \%$ silica gel with a reduction of $67 \%$ compared with the control. The maximum reduction in extracted $\mathrm{Cd}, \mathrm{Cr}$ and $\mathrm{Pb}$ resulted by the mixture of charcoal + silica gel $(0.33 \mathrm{ppm} \mathrm{Cd})$, rock phosphate + silica gel and cement By-pass + silica gel $(0.04 \mathrm{ppm} \mathrm{Cr})$ and rock phosphate + cement By-pass $(9.98 \mathrm{ppm} \mathrm{Pb})$, respectively. While, the mixture of silica gel with any other amendment under study always retained $100 \%$ of the extracted $\mathrm{Ni}$.
\end{abstract}

Keywords: Silica gel, Cement Bypass, Rock phosphate and charcoal activated carbon, Stabilization, Sewage sludge

The growing population of Egypt demand growing production of food which makes the governorate encourage people to reclaim and use desert areas which are in great need for organic fertilizers. The most commonly heavy metals found in biosolid are $\mathrm{Pb}, \mathrm{Ni}, \mathrm{Cd}, \mathrm{Cr}, \mathrm{Cu}$ and $\mathrm{Zn}$ (Mattigod and Page, 1983). Clay, zeolite, minerals, phosphates, cement, organic compost, microbes (Fin Zgar et al., 2006) and red mud (Lombi et al., 2002) are mostly applied as amendments. Udeigwe et al. (2011) concluded that the immobilization mechanisms of contaminant could include: 1) Preciptaton as salts, 2) Co-precipitation 3) Surface precipitation 4) adsorption to mineral surfaces (ion exchange and formation of stable complexes). The dissolved organic carbon forms complexes with a large portion of $\mathrm{Cd} \mathrm{n}$ soils containing large amounts of organic matter (Sauve et al., 2000). A linear relationship was obtained by Hyun et al. (1998) between organic carbon and soluble $\mathrm{Cd}$ in solution forming metal-organic complex in sludgetreated soils. Chen et al. (2010) and Hua et al. (2009) reported a high adsorption capacity for heavy metals on bamboo charcoal due to its large negatively charged surface area and the high surface density of functional groups and metal oxides. They also concluded that Bamboo charcoal has five times greater porosity and 
ten times higher adsorption efficiency than that of wood charcoal. Studying the enhancement of heavy metals stabilization in sewage sludge, Chiang et al. (2007) reported that the increasing applied coal fly ash to sewage sludge (from 0 to $20 \%$ ) decreased DTPA-Pb in sludge from 40 to $21 \%$. While an insignificant decrease in DTPA-Cu, $\mathrm{Zn}$ and $\mathrm{Ni}$ were found with the same application. The surface of silica gel consists of inter connected particles forming a three dimensional skeleton. Silica gel has high surface area (Jiang et al., 2007), porosity and rigid structure (Repo et al., 2011), it is also characterized by highly porous texture (Fenglian and Wang, 2011).

Amin (2013) reported that the constituents of cement By-pass collected from Assiut cement company were $11.88 \% \quad \mathrm{SiO}_{2}, 2.97 \% \mathrm{Al}_{2} \mathrm{O}_{3}, 2.60 \% \quad \mathrm{Fe}_{2} \mathrm{O}_{3}, 47.8 \%$ $\mathrm{CaO}, 0.68 \% \quad \mathrm{MgO}, 12.13 \% \quad \mathrm{SO}_{3}, 2.28 \mathrm{Na}_{2} \mathrm{O}, 4.38 \% \quad \mathrm{~K}_{2} \mathrm{O}$ and $4.81 \% \mathrm{Cl}$. The total available $\mathrm{Pb}, \mathrm{Cd}$, and $\mathrm{Ni}$ were decreased by 10-20, 30-40 and 25-30\%, respectively, with the application of cement dust to amended soil (Abou-Seeda et al., 2005). Treating sludge with cement kiln dust reduced the solubility and increased the immobilization of heavy metals in the treated sludge matrix (Emmerich et al., 1982). Kigel et al. (1994) showed that the application of cement kiln dust stabilized chromium in waste sludge. A reduction in $\mathrm{Cu}$ and $\mathrm{Zn}$ mobility andimmobilization of $\mathrm{Pb}$ were reported Ownby et al. (2005) when using phosphorus containing materials. Both ionic exchange and precipitation of poorly soluble products are the main reasons of $\mathrm{Pb}$ mobility reduction when $\mathrm{Pb}$-impacted soil receives phosphste amendments (Scheckel et al., 2005). Bolan et al. (2003) explained the induced immobilization of $\mathrm{Cd}$ by phosphate application by: 1) the adsorption of $\mathrm{Cd}^{2+}$ on phosphate 2) the precipitation of $\mathrm{Cd}(\mathrm{OH})_{2}$ and $\mathrm{Cd}_{3}\left(\mathrm{PO}_{4}\right)_{2}$. They also reported that $\mathrm{Cd}^{2+}$ adsorption on phosphate were due to several mechanisms such as: 1) increasing of $\mathrm{pH}, 2$ ) increasing of serface charge, 3) Co-adsorption of phosphate and $\mathrm{Cd}$ as an ion pair, and 4) surface complexes formation of $\mathrm{Cd}$ on the phosphate compounds. According to Naidu et al. (1996), the net negative charge of variable charge surfaces increases when a specific adsorption of anions occurs which increases the retention of metal cations such as $\mathrm{Cd}^{2+}, \mathrm{Cu}^{2+}$ and $\mathrm{Zn}^{2+}$ (Boland et al., 1999). McGowen et al. (2001) reported that high levels of diammonium phosphate $\left(2300 \mathrm{mg} \mathrm{kg}^{-1}\right)$ application to a smelter-contaminated soil resulted in immobilizing $\mathrm{Cd}, \mathrm{Pb}$ and $\mathrm{Zn}$.

This study aims to evaluate the effect of some soil amendments (silica gel, rock phosphate, cement By-pass and Charcoal activated carbon on the in situ stabilization of certain heavy metals $(\mathrm{Cd}, \mathrm{Cr}, \mathrm{Ni}$ and $\mathrm{Pb})$ in sewage sludge.

\section{Material and Methods}

Most of wastewater treatment plants in Egypt pumps wastewater into gravity thickeners leaving the remained sewage sludge to be naturally dewatered and air dried. Sewage sludge was collected from Elmadabigh Sewage Plant, Assiut, air dried and left in the Soil Laboratory for Analysis and Technical Consultations, Assiut University, Egypt. In order to minimize heavy metals availability from sewage sludge, four materials were used: Silica gel (100-200 Mesh), Cement Bypass (CB), Rock phosphate (RP) and Charcoal activated powder (AC). Three 
rates of each material $\left(5,15\right.$ and $25 \% \mathrm{w} \mathrm{w}^{-1}$ sewage sludge $)$ and a mixture of $15 \%$ of each two compound were mixed thoroughly with the sludge and each treatment was replicated three times. Cement By-pass is an industrial byproduct produced from cement industry (Assiut Cement Company) in huge amounts (about 150 ton $\mathrm{day}^{-1}$ ). This byproduct is a very fine powdered containing significant level of $\mathrm{CaO}$, iron, silicon, aluminum oxides and some other oxides in small amounts ( $\mathrm{Zn}, \mathrm{Cu}, \mathrm{Mn}$ and some heavy metals).

Sewage sludge was mixed with the different materials under study. Water was added to the samples when needed every day for three weeks to maintain the moisture content stable in the mixture. Sludge was found to contain $52.3 \%$ organic matter, $6 \%$ nitrogen, $1.9 \% \mathrm{P}_{2} \mathrm{O}_{5}, 0.72 \% \mathrm{~K}_{2} \mathrm{O}, 11.9 \% \mathrm{CaO}$ and $5.8 \% \mathrm{MgO}$. The total content of studied heavy metals in sludge was 3.1, 249, $0.9 \mathrm{ppm}$ and 58.7 for $\mathrm{Cd}, \mathrm{Pb}, \mathrm{Cr}$ and $\mathrm{Ni}$. Samples were left in the lab to dry for another week then extracted using 0.1M Diethylene Triamine Penta Acetic Acid (DTPA) according to Lindsay and Norvell (1978). Cadmium, $\mathrm{Ni}, \mathrm{Cr}$ and $\mathrm{Pb}$ were determined using Inductively Coupled Plasma Atomic Emission Spectrometry (ICAP 6200). For statistical analysis results were conducted in a simple experiment and the treatments were arranged in a complete randomized block design with three replicates. The MSTATC 2.10 computer program written by Freed (1992) was used to perform analysis of variance. The obtained data were subjected to statistical analysis of variance according to Gomez and Gomez (1984), the means of treatments were tested using the least significant difference method (LSD) at $\mathrm{P}=0.05$.

\section{Results and Discussion}

Effects of different amendment types and rates on DTPA extractable heavy metals:

The application of silica gel always increased the extractable $\mathrm{Cd}, \mathrm{Ni}$ and $\mathrm{Pb}$ significantly with a gradual decrease in extracted metals with increasing silica gel rates (Fig. 1). Kosmulski (2000) reported that silica shows a significant solubility exceeding $1 \mathrm{mmol} \mathrm{dm}^{-3}$ in acidic and neutral aqueous solutions and that the dissolved silica species in solution can be comparable with or higher than the concentration of active surface sites at a sufficiently low solid- to- liquid ratio. Due to silica solubility in basic $\mathrm{pH}$ values, the same researcher concluded that heavy metals adsorption on silica may be affected by 1) the silica species in solution that can compete with the surface sites for heavy metal cations 2) The silica species can interact with adsorbed metal cations to build phases of springly soluble metal silicates. While, extracted $\mathrm{Cr}$ reached its lowest value with a reduction by $67 \%$ compared with the control. To explain the effect of silica on $\mathrm{Cr}$ adsorption, Kosmulski (2000) reported that sorption of some heavy metal cations on silica is significantly depressed when the concentration of alkaline-earth metal cations is comparable with the concentration of surface hydroxyl groups but sorption of some other heavy metal cations remains unaffected. 
Cement By-pass (CB) application at any rate resulted in significant reduction in DTPA extractable $\mathrm{Pb}, \mathrm{Ni}$ and $\mathrm{Cr}$. The highest reduction occurred with the application of $15 \% \mathrm{CB}$ which resulted in decreasing DTPA extractable $\mathrm{Pb}, \mathrm{Ni}$ and $\mathrm{Cr}$ by 44,47 and $56 \%$, respectively, compared with the control. Applying $100-2000 \mathrm{mg} \mathrm{L}^{-1}$ of cement kiln dust to solutions containing $100-800 \mathrm{mg} \mathrm{L}^{-1}$ of $\mathrm{Zn}^{2+}, \mathrm{Al}^{3+}, \mathrm{Co}^{2+}$ and $\mathrm{Cd}^{2+}$ removed $95 \%$ of the metals with a gradual decrease in removed ions with increasing concentrations above $800 \mathrm{mg} \mathrm{L}^{-1}$ (Waly et al., 2010). While Cd increased gradually with the application of $\mathrm{CB}$ to reach $96 \%$ higher than the control with the application of $25 \% \mathrm{CB}$. The application of $2 \%$ cement By-pass to El-Gabal El-Asfar contaminated soil increased the exchangeable form of $\mathrm{Zn}, \mathrm{Cu}, \mathrm{Pb}$ and $\mathrm{Cd}$ to reach $634,74,14$ and $77 \%$, respectively, compared with the control, while a decrease in soluble $\mathrm{Zn}$ by $77.3 \%$, compared with the control, was observed (Amin, 2013).

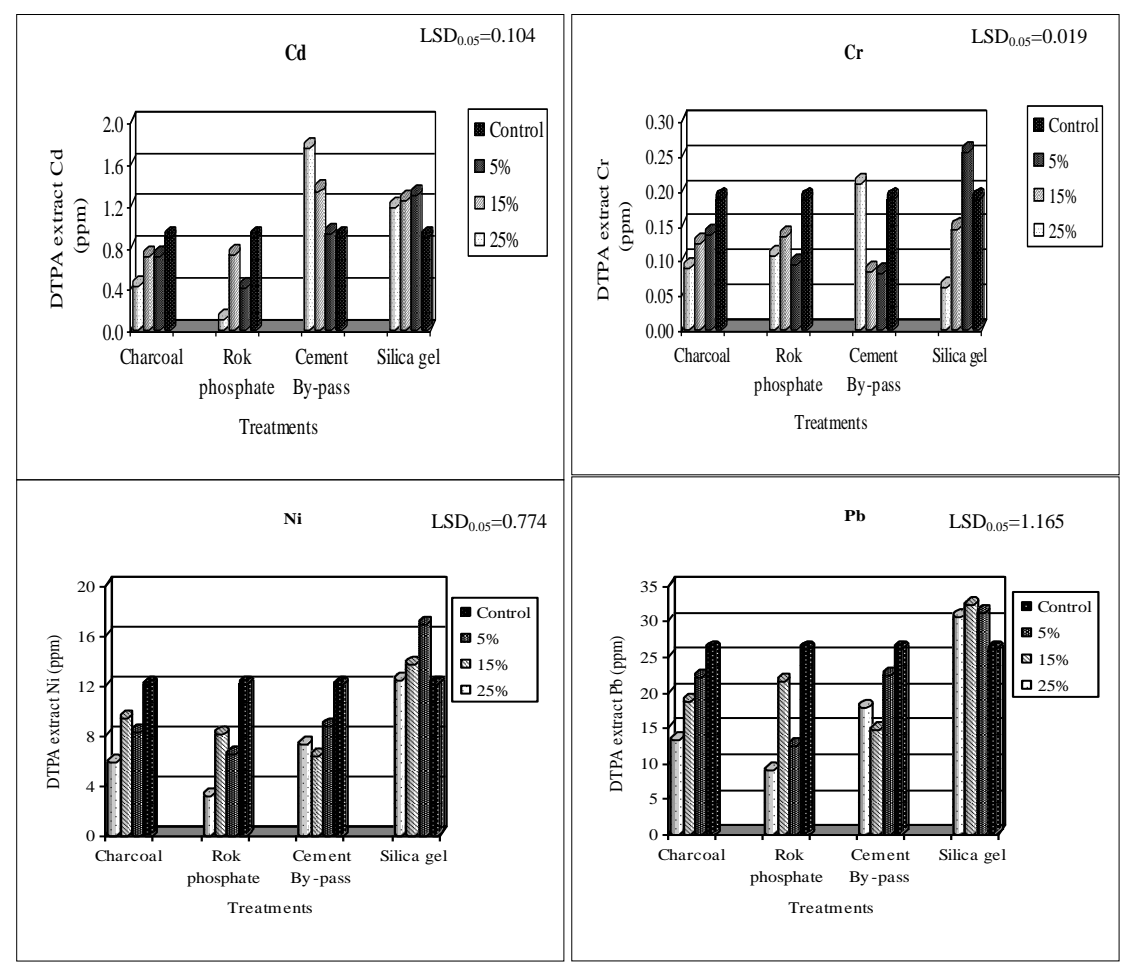

Fig. 1. Effect of charcoal active carbon (AC), cement By-pass (CB), silica gel (SI) and rock phosphate (RP) application on DTPA extractable $\mathrm{Cd}, \mathrm{Cr}$, Ni and Pb (ppm).

All rock phosphate treatments (RP) significantly decreased all extracted metals under investigation. The decrease in extracted $\mathrm{Cd}, \mathrm{Cr}, \mathrm{Ni}$ and $\mathrm{Pb}$ were 54 , 50,47 and $52 \%$ with 5\% RP, 18, 29, 33 and 17 with 15\%RP and 58, 43, 74 and $65 \%$ with $25 \% \mathrm{RP}$ application, respectively, compared with the control. These numbers shows that the amounts of stabilized metals were higher with the application of 5 and $25 \% \mathrm{RP}$ compared with $15 \% \mathrm{RP}$. The explanation of this behavior according to Sen et al. (2002) who found a physical effect between the

Egypt. J. Soil Sci. 56, No.1 (2016) 
individual particles having a high solid-to-solution ration which lead to coagulate and flocculate into larger particles with less available surface for adsorption. This explanation is correct when the applied RP increased from 5 to $15 \%$ leading to decrease the retention of metals on RP particles. On the other hand, increasing the applied RP up to $25 \%$ resulted in increasing the total surface area (compared with 5 and $15 \%$ RP application) wither in large particles or in small ones leading to increase all the reaction processes that stabilize metals. The main mechanisms in immobilizing metals such as $\mathrm{Pb}$ and $\mathrm{Zn}$ by phosphate compounds are precipitation as metal phosphate (Pierzynski and Schwab, 1993) and surface complexation of metals by hydroxyapatite (Xu et al., 1994).

Charcoal activated carbon (AC) application gradually and significantly decreased almost all discussed elements having the maximum effect with the application of $25 \% \mathrm{AC}$ with a decrease of $52,52,51$ and $49 \%$ for $\mathrm{Cd}, \mathrm{Cr}, \mathrm{Ni}$ and $\mathrm{Pb}$, respectively, compared with the control. Active carbon (black carbon and charcoal) is used as adsorbent materials for filtration and water treatment for its high surface area (Day and Vlassopoulos, 2010).

Combined effect of different amendment types on DTPA extractable heavy metals

Figure 2 shows a comparison between the DTPA extractable metals in the untreated sludge samples and after application of each treatment alone in a ratio of $15 \%$ and the mixture of each two treatments in a ratio of $15 \%$ of each. Generally, mixing any two amendments together with the sludge resulted in significant reduction in DTPA extractable metals. The maximum reduction in extracted $\mathrm{Cd}, \mathrm{Cr}$ and $\mathrm{Pb}$ were found when silica gel was mixed with $\mathrm{AC}(0.33 \mathrm{ppm} \mathrm{Cd}), \mathrm{CB}(0.04 \mathrm{ppm} \mathrm{Cr})$ and RP (9.98 and $0.04 \mathrm{ppm} \mathrm{Pb}$ and $\mathrm{Cr}$, respectively). Contaminants may be physically bound in nano-to microscale inclusions or chemically bound as sorbed or precipitated nanoparticles within another resistant medium in a mechanism called "Microencapsulation", silica and cement-based amendments provide an example of Microencapsulation that reduces contaminant partitioning into pore water (Day and Vlassopoulos, 2010). Dissolved toxic divelent cations, such as $\mathrm{Pb}^{2+}$ in contaminated soils can be immobilized using phosphate due to the precipitation of pure or substituted phosphate phase of the apatite group (Miretzky and Fernandez-Cirelli, 2008). The formation of secondary metal phosphate precipitates resulted in the decrease in the solubility of a range of metals in the presence of hydroxyapatite (Seaman et al., 2001).

On the other hand, mixing silica gel with any of the other amendments under discussion always resulted in $100 \%$ reduction of extracted Ni. Charlet and Manceau (1994) suggested formation of clay minerals upon sorption of Co and $\mathrm{Ni}$ on silica; this phenomenon is accompanied by a slow change from a tetrahedral to an octahedral co-ordination. Also, Hayes and Leckie (1987) reported that heavy metal cations form inner sphere complexes with the surface of silica, while alkaline earth metal cations form outer sphere complexes.

The effect of silica gel on heavy metals stabilization that appears when mixing it with other substances needs further attention and studies for explanation. 


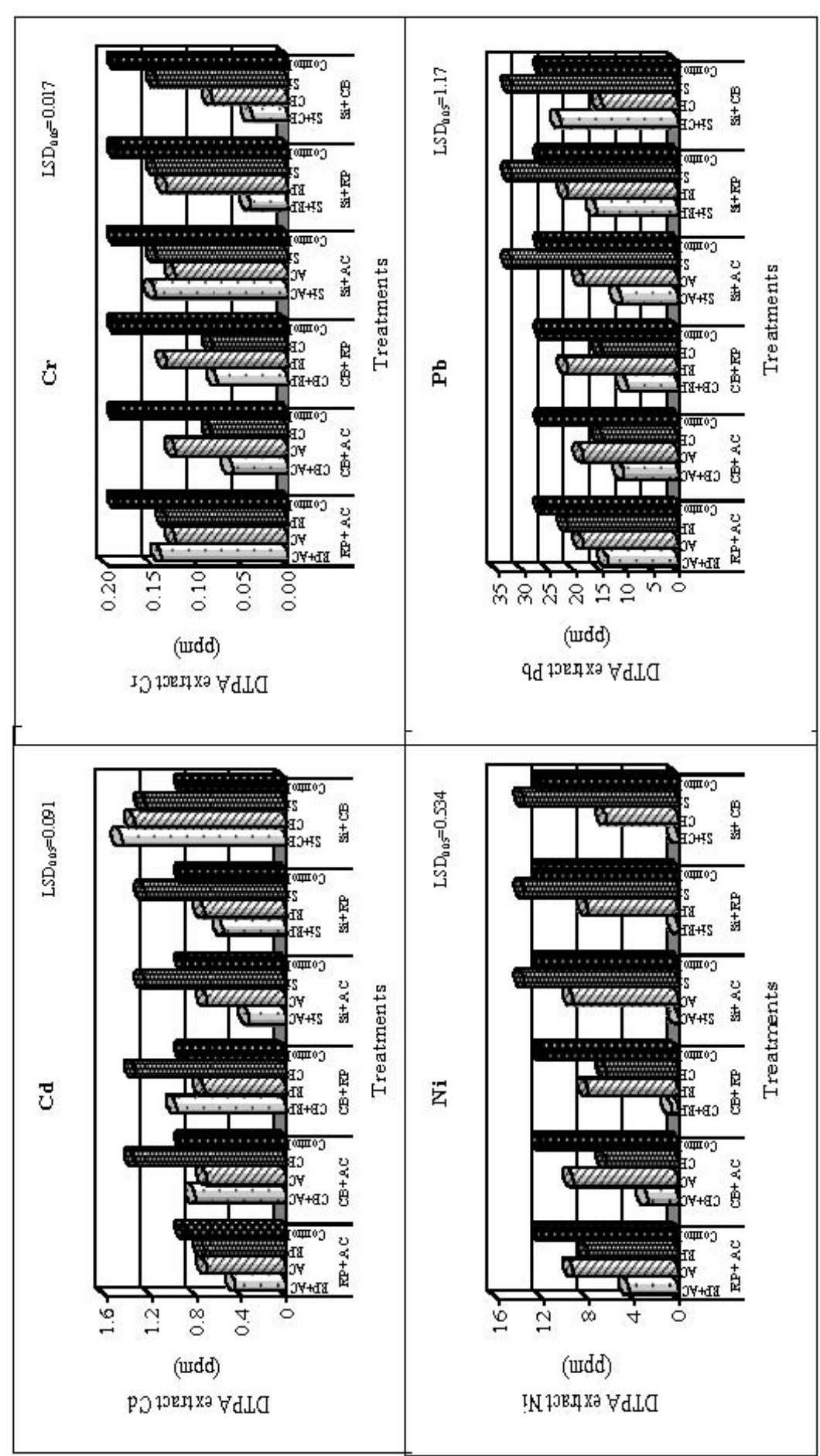

跣

Egypt. J. Soil Sci. 56, No.1 (2016) 


\section{References}

Abou-Seeda, M., Zaghloul, A.M. and AbdEl-Galil, A. (2005) The role of cement dust in chemical remediation of the sludge treated soil. Assiut Univ. Bull. Environ. Res. 8, 89- 107.

Amin, A.A. (2013) Evaluation of using certain industrial wastes in the reclamation and remediation of some soils.Ph.D. Thesis, Fac. Agric., Assiut Univ., Egypt.

Bolan, N.S., Adriano, D.C., Mani, P., Duraisamy, A. and Arulmozhiselvan, A. (2003) Immobilization and phytoavailability of cadmium in variable charge soil: I. Effect of phosphate addition. Plant and Soil 250, 83- 94.

Boland, N.S., Naidu, R., Khan, M.A.R. and Tillman, R.W. (1999) The effect of anion sorption on sorption and leaching of cadmium. Australian J. of Soil Research 37, 445460 .

Chaiang, K.Y., Huang, H.J. and Chang, C.N. (2007) Enhancement of heavy metal stabilization by different amendements during sewage sludge composting process. $J$. Environ. Eng. Manage., 17(4), 249- 256.

Charlet, L. and Manceau, A. (1994) Geochem Cosmochim. Acta, 58, 2577.

Chen, Y.X., Huang, X.D., Han, Z.Y., Huang, X., Hu, B., Shi, D.Z. and Wu, W. X. (2010) Effects of bamboo charcoal and bamboo vinegar on nitrogen conservation and heavy metals immobility during pig manure composting. Chemosphere. 78, 11771181 .

Day, P.A. and Vlassopoulos, D. (2010) Mineral- Based amendments for remediation. Elements (Que). 6(6), 375- 381.

Emmerich, W.E., Lund, L.J., Page, A.L. and Chang, A.C. (1982) Movement of heavy metals in sewage sludge- treated soils. J. Environ. Qual. 11, 174- 178.

Fenglian, F. and Q. Wang (2011) Removal of heavy metal ions from wastewaters: A review. Journal of Environmental Management. 92, 407- 418.

Fiňzgar, N., Kos, B. and Le`stan, D. (2006) Bioavailability and mobility of $\mathrm{Pb}$ after soil treatment with different remediation methods. Plant, Soil and Environment, vol 52, no. 1, pp. 25-34, 2006.

Freed, R. D. (1992) MSTAT-C Software Program (Version 2.10). Crop and Soil Sciences Department, Michigan State University, USA.

Gomez, K.A. and A.A. Gomez. (1984) Statistical Procedures for the Agricultural Research. $2^{\text {nd }}$ Edition, John Wiley and Sons, Inc., New York.

Hayes, K.F. and Leckie, J.O. (1987) J. Colloid. Interf. Sci. 115, 547.

Hua, I., Wu, W., Liu, Y., Bride, M.B.M. and Chen, Y. (2009) Reduction of nitrogen loss and $\mathrm{Cu}$ and $\mathrm{Zn}$ mobility during sludge composting with bamboo charcoal amendment. Environ. Sci. Pollut. Res. 16, 1-9. 
Hyun, H., Chang, A.C., Parker, D.R. and Page, A.L. (1998) Cadmium solubility and phytoavailability in sludge- treated soil: Effects of soil organic matter. J. Environ Qual. 27, 329- 334.

Jiang, Y., Geo, Q., Yu, H., Chen, Y. and Deng, F. (2007) Intensively competitive adsorption for heavy metal ions by PAMAM-SBA-15 and EDTA-PAMAM-SBA-15 inorganic- organic hybrid materials. Micropor. Mesopor. Mater. 103, 316- 324.

Kigel, M.Y., Shultis, J.F., Goldman, E.S. and Demytrk, M.K. (1994) Method of detoxification and stabilization of soils contaminated with chromium ore waste. Patent and Trademark Office, United States Department of Commerce, Washington DC, USA, Patent No: 5, 304, 710 .

Kosmulski, M. (2000) Sorption of heavy metal cations on silica. In: Adsorption on Silica Surfaces edited by Eugene Papirer. Surfactant science series 90, 399- 437.

Lindsay W.L. and Norvell, W.A. (1978) Development of a DTPA soil test for zinc, manganese and copper. Soil Sci. Soc. Am. J. 42, 421-428.

Lombi, E., Zhao, F.J., Zhang , G. In situ fixation of metals in soils using bauxite residue: chemical assessment, Environmental Pollution, vol. 118, no. 3, pp. 435-443, 2002.

Mattigod, S. V. and Page, A. L. "Assessment ofmetal pollution in soil," in Applied Environmental Geochemistry, pp. 355-394, Academic Press, London, UK, 1983.

McGowen, S.L., Basta, N.T. and Brown, G.O. (2001).Use of diammonium phosphate to reduce heavy metal solubility and transport in smelter- contaminated soil. $J$. Environ. Qual. 30, 493- 500.

Miretzky, P. and Fernandez-Cirelli, A. (2008) Phosphate for $\mathrm{Pb}$ immobilization in soils: A review. Environ. Chem. Letters. 6, 121- 133.

Naidu, R., Kookana, R.S., Sumner, M.E., Harter, R.D. and Tiller K.G. (1996) Cadmium adsorption and transport in variable charge soils: a review. J. Environ. Qual. 26, 602- 617 .

Ownby, D.R., Galvan, K.A. and Lydy, M.J. (2005) Lead and zinc bioavailability to Eisenia fetida after phosphorus amendment to repository soils. Environ. Pollut. 136, 315- 321

Pierzynski, G.M. and Schwab, A.P. (1993) Bioavailability of zinc, cadmium and lead in a metal contaminated alluvial soil. J. Environ. Qual. 22, 247- 254.

Repo, E., Warchol, J.K., Bhatnagar, A. and Sillanpaa, M. (2011) Heavy metals adsorption by novel EDTA- modified chitosan- silica hybrid materials J. Colloid. Interface Sci. 358 (1), 261- 267.

Sauve, S., Norvell, W.A., McBride, M. and Hendershot, W. (2000) Speciation and complexation of cadmium in extracted soil solutions. Environ. Sci. and Technol. 34, 291- 296. 
Scheckel, K.G., Ryan, J.A., Allen, D. and Lescano, N.V. (2005) Determining speciation of $\mathrm{Pb}$ in phosphate- amended soils: method limitations. Sci. Total Environ. 350, 261272.

Seaman, J.C., Arey, J.S. and Bertsch, P.M. (2001) Immobilization of nickel and other metals in contaminated sediments by hydroxyapatite addition. J. Environ. Qual. 30, 460- 469 .

Sen, T.K., Mahajan, S.P. and Khilar, K.C. (2002) Adsorption of $\mathrm{Cu}^{2+}$ and $\mathrm{Ni}^{2+}$ on iron oxide and kaolin and its importance on $\mathrm{Ni}^{2+}$ transport in porous media. Colloids and surfaces A. physicochem. Eng. Aspects. 211, 91- 102.

Udeigwe, T.K., Eze,P.N. Teboh, J.M. and Stietiya, M.H. (2011) Application, chemistry and environmental implications of contaminant-immobilization amendments on agricultural soil and water quality. Environ International. 37 (1), 258- 267.

Waly T.A., Dekroury A.M., El-Sayed, G.O. and El-Salam, S.A. (2010) Assessment removal of heavy metals ions from wastewater by cement kiln dust (CKD). J. Am. Sci. 6(12), 910- 917.

Xu, Y., Schwartz, F.W. and Traina, S.J. (1994) Sorption of $\mathrm{Zn}^{2+}$ and $\mathrm{Cd}^{2+}$ on hydroxyapatite surfaces. Environ. Sci. and Technol. 28, 1472- 1480.

(Received 25/3/2015;

accepted $9 / 4 / 2015$ 


$$
\begin{aligned}
& \text { تثبيث العناصر الثقيلة في مخلفات المجارى الصلبة (الحمأه) } \\
& \text { باستخدام بعض محسنات التربة } \\
& \text { هاله حسنين جمعه الأر اضى والمياه ـ كلية الزر اعة - جامعة أسيوط - أسيوطـ مصر. }
\end{aligned}
$$

هذا البحث يناقش خفض محتوى مخلفات المجارى الصلبة (الحمأه) من العناصر

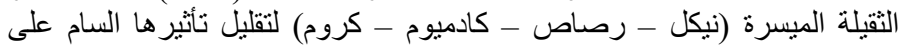

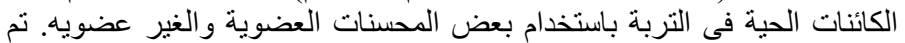

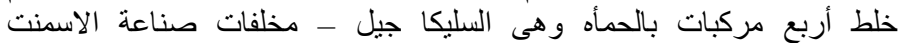
(cement By-pass)

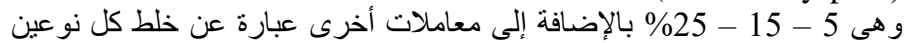
من المحسنات معا بنسبة 15\% بكل محسن ثم خلطهم مع الحمأه.

أظهرت النتائج انخفاض الكميه المستخلصة من الكادميوم - النيكل -

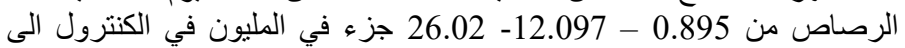

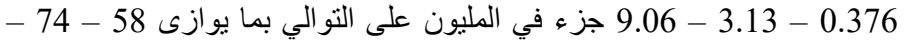

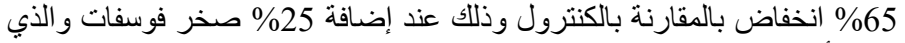

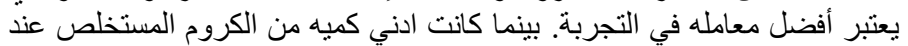

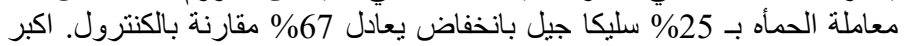

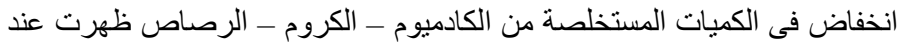

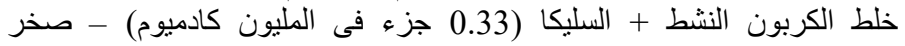

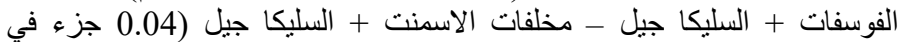

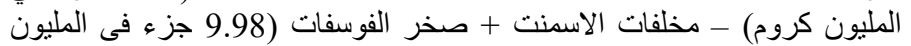
رصاص) على التو الي. بينما أدى خلط السليكا جيل مع أي محسن أخر إلى انخفاض الملي النيكل المستخلص بنسبة 100\%. 